\title{
Genetic diversity and similarity of pear (Pyrus communis L.) cultivars in Central Europe revealed by SSR markers
}

\author{
Gitta M. Kocsisné · Dávid Bolla • Ulrike C. M. Anhalt-Brüderl • \\ Astrid Forneck · János Taller • László Kocsis
}

Received: 5 August 2019/Accepted: 6 April 2020/Published online: 17 April 2020

(C) The Author(s) 2020

\begin{abstract}
The Hungarian pear gene bank, located and founded in Keszthely in 1981, contains 210 pear cultivars including regional cultivars, cultivars of foreign origin and standard commercial cultivars. There are some cultivars with synonym names in the pear gene bank and in other pear growing areas within the Hungary. The aim of our work was to systematically analyse the genotypes of Hungarian cultivars in the pear gene bank and to set up a robust protocol for molecular identification and the interpretation of data. Eighty-eight cultivars were analysed employing eight SSR primers resulting in a total of 216 alleles. Seventy-seven cultivars were thoroughly analysed. Among the samples 29 were considered to be diploids and 59 triploids. A genetic diversity analysis was computed based on a Neighbour-Joining algorithm
\end{abstract}

G. M. Kocsisné $(\varangle) \cdot$ D. Bolla $\cdot$ J. Taller

Department of Plant Science and Biotechnology,

Georgikon Faculty, University of Pannonia, Deák F. u. 16,

Keszthely, Hungary

e-mail: kmgitta@hotmail.com

U. C. M. Anhalt-Brüderl · A. Forneck

Division of Viticulture and Pomology, Department of Crop Sciences, University of Natural Resources and Life Sciences Vienna, Konrad- Lorenz Str. 24, 3430 Tulln, Austria

\section{Kocsis}

Horticultural Department Hungary, Georgikon Faculty, University of Pannonia, Deák F. u. 16, Keszthely, Hungary and combined with a PCA indicating close genetic relationship and an overall high amount of genetic diversity among the samples tested. Similarities and very close relations were verified in our studies between different pear cultivar variants: 'Korai szagos' A and B, which were planted with the same name in the gene bank. Six different 'Császár körte' and three 'Köcsög körte' cultivars were compared. It was important to establish how close their relationship was. Some cultivars originating from the same regions were compared. The 'Mezökövesdi $2^{\prime}$ and ' 3 ' are in the same main branch, however their distance is larger, the number of common alleles is less than those of the two 'Erdélyi körte' cultivars.

Keywords Genetic diversity - Relationship · Pear . Gene bank

\section{Introduction}

The leading pear (Pyrus communis L.) growing countries in Europe are Italy $(700,000$ t), Spain $(400,000 \mathrm{t})$, Belgium and the Netherlands. In the countries of the European Union production is stable at 2-2.5 million tonnes. The most widespread cultivars are 'Conference' and 'Williams', with about $14 \%$ each, followed by 'Abbé Fétel'. 'Williams' production has been steady between 250,000 and 300,000 ha in the last few years. 'Abbé Fétel', mostly 
produced in Italy, is over 250,000 tonnes, whereas the production of the Spanish 'Blanquilla' has been over 200,000 tonnes in the last years.

The more than 100,000-ton annual production of Hungary of the 1980s has decreased to $30-40,000$ tons today. About 4500 ha of Hungary's territory are suitable for growing pears because most of the cultivars that we grow come from the cooler and more humid areas of Western Europe, but production takes place only on 2350 ha. Pears can be produced successfully in two regions of the country: in Zala County and Szabolcs- Szatmár-Bereg County. Of the many different cultivars the production of two cultivars dominates: 'Beurré Bosc' (32\%) and 'Williams' $(20 \%)$ are grown at the highest rate. Other cultivars such as 'Conference', 'Packham's Triumph', 'Clapp's favourite' and 'Beurré d' Hardenpont' are cultivated at a smaller rate (Ledó 2016). In order to extend the choice of cultivars in Hungary, it would be important to spread those which are resistant to bacterial branch decay caused by Erwinia amylovora, e.g. 'Harrow Sweet' and 'Concorde' (Göndörné 2000).

In Western Europe one of the biggest pear gene banks can be found at the University of Milan. As many as 309 of these varieties are models of different pear varieties. With another 231 models from different sources, about 500 pear varieties are represented. This collection shows the great number of pear varieties grown in Northern Italy 150 years ago. (Eccher and Pontirolo 2005). In Italy 780 varieties of pears can be found in both the private and state pear collections (Bellini et al. 2003). Probably the biggest pear gene bank in the world can be found in Oregon, maintained by the US Department of Agriculture, Agricultural Research Service (USDA-ARS), where there are more than 2,500 unique clones and seedlings. Seed and seedling collections usually represent species populations from distinct geographic locations rather than unique genotypes (Postman 2019).

In Hungary Brózik started to collect the different species and varieties of fruits in the Experimental Stock Orchard of the University of Horticulture in Kamaraerdő. He collected nearly 1000 genotypes (Brózik et al. 1976). In 1976 he proposed to establish a pear gene bank in Keszthely, as he found the growing area of Zala County optimal (Iváncsics 1994).

Brózik gave great help to collect the material of the gene bank in Keszthely (located on the western shore of Lake Balaton) in 1981. Today there are 250 pear cultivars in our pear gene bank in Hungary. The gene bank started to plant pears in Keszthely in 1981. Among these pear cultivars we can find a lot of Hungarian regional cultivars, which are under continuous screening. Many regional cultivars in the country and the orchard of our gene bank have the same names.

The conservation of natural genetic material with special or valuable horticultural characters for future plant breeding can be carried out in suitable gene banks. From 1990 onwards, efforts have been made to establish a central database and a national collection of native genetic resources in Hungary (Labuschagne et al. 2011).

The protection of natural gene resources and the storage of the genotypes and cultivars of valuable biological and production features for the future improvement tasks is only possible in suitable gene banks. Detailed data collection is carried out concerning the items of the gene banks, recording more than 25 features and measured data, which are suitable for their identification, central registration, and they are accessible to local and foreign researchers, lecturers, improvers and others who are interested (Kocsisné 2006).

The aim of our work was to systematically analyse the genotypes of Hungarian cultivars in the pear gene bank and to set up a robust protocol for molecular identification and the interpretation of data. Based on our results we will be able to establish the relationships and genetic diversity of the pear cultivars and genotypes. SSRs have become markers of choice because they are highly informative, reliable, and easy to use for cultivar identification, thereby improving the management of collections by enabling the identification of duplicates, synonyms, and homonyms. They are also valuable tools to understand the origins of local varieties, and to ascertain the importance of introgression, polyploidy, and hybridization in their evolution (Queiroz et al. 2019).

Genetic maps are essential tools for pear genetics and genomics research. Integrated simple sequence repeat (SSR) and single nucleotide polymorphism (SNP)-based consensus genetic maps for pear based on common SSR markers between nine published maps were studied by Li et al. (2017). A total of 5085 markers, including 1232 SSRs and 3853 SNPs, were localized on a consensus map spanning $3266.0 \mathrm{cM}$ in total, with an average marker interval of $0.64 \mathrm{cM}$, which represents the highest density consensus map of 
pear to date. The integrated high-density SSR and SNP-based consensus genetic map provided new insights into the genetic structure patterns of pears (Li et al. 2017).

Kim et al. (2015) aim was to determinate the taxonomic relationship among pear cultivars. Twentysix European pears (Pyrus spinosa Forssk., Pyrus communis L., Pyrus elaeagrifolia Pall., Pyrus x nivalis Jacq.), 18 Asian pears Pyrus pyrifolia (Burm.f.) Nakai, and 4 hybrids $(P$. communis $\times P$. pyrifolia $)$ were classified and identified using seven simple sequenced repeats 7 SSR markers. Unweighed pair-group method of arithmetic averages cluster analysis results were classified into two main groups. The first group included Asian pear P. pyrifolia and some hybrids. The second group contained European pear $(P$. communis) and also $P$. $x$ nivalis and $P$. spinosa was on the outside of it.

\section{Material and methods}

\section{Plant material}

The plant material of 81 cultivars were obtained from the pear gene bank at the University of Pannonia, Georgikon Faculty, Department of Horticulture in Keszthely, Hungary. The collection contained autochthone cultivars, cultivars of foreign origin, and commercial cultivars (Table 1). Seven cultivars from the practical station from BOKU in Jedlersdorf, Austria were additionally included in the analysis. They were chosen as standards to compare the allele sizes to other studies (Sehic et al. 2012).

\section{DNA extraction}

Young leaves were collected of each variety, snap frozen and stored at $-20{ }^{\circ} \mathrm{C}$ until the DNA extraction. Genomic DNA was extracted using the E.Z.N.A. SP Plant DNA Miniprep Kit (Omega Biotek, Doraville, USA) following the manufacturer's instructions with one modification: prolonging the incubation step to 30 min according to Barth et al. (2009).

\section{SSR analysis}

DNA and technical replicates were included in the analysis to provide evidence of the reproducibility of the method. Simple sequence repeat (SSR) markers were chosen as suggested by the European Cooperative Program for Plant Genetic Recourses (ECPGR) (Evans et al. 2009). PCR reactions were carried out in a total volume of $10 \mu \mathrm{l}$ containing $20 \mathrm{ng}$ total genomic DNA as a template, $2.5 \mu \mathrm{M}$ forward and reverse primers (Sigma Aldrich, St. Louis, Missouri, US), 0.3 $\mathrm{U}$ of DNA Taq polymerase (Promega, Madison, Wisconsin, US) and $2 \mathrm{mM}$ dNTPs in a PeqLab thermocycler (Erlangen, Germany). The thermocycler program was as follows: (1) $94{ }^{\circ} \mathrm{C}$ for $5 \mathrm{~min}$, (2) 10 cycles of: $94{ }^{\circ} \mathrm{C}$ for $30 \mathrm{~s}, 55-50{ }^{\circ} \mathrm{C}\left(-0.5{ }^{\circ} \mathrm{C} /\right.$ cycle $)$ for $45 \mathrm{~s}, 72{ }^{\circ} \mathrm{C}$ for $1 \mathrm{~min}$, (3) 25 cycles of: $94{ }^{\circ} \mathrm{C}$ for $30 \mathrm{~s}, 50{ }^{\circ} \mathrm{C}$ for $45 \mathrm{~s}, 72{ }^{\circ} \mathrm{C}$ for $1 \mathrm{~min}$ and $(4) 72{ }^{\circ} \mathrm{C}$ for $15 \mathrm{~min}$. Detecting and displaying the results happened on a Fragment Analyzer (Advanced Analytical, Heidelberg, Germany) with the ProSize program (Advanced Analytical, Heidelberg, Germany).

Analysis of the genetic structures

To display the data statistically we used the DarWin (Perrier and Jacquemoud-Collet 2006) statistical program. Heterozygosity was observed and calculated as published in Forneck et al. (2015). Since we found accessions which had different ploidy stadium, we had to transfer the SSR Data into a binary matrix. If the allele is present a (1), and if not present a (0). A Factorial analysis using Principal Coordinates Analysis (PCoA) was used. To calculate an Unweighted Neighbor Joining Tree after Saitou and Nei (1987) and Gascuel (1997) all 88 cultivars were used to calculate the tree distances involving the observed dissimilarities.

\section{Results and discussion}

Evaluation of SSR polymorphism

88 pear cultivars were tested by eight SSR markers to give $8 \times 88=704$ results to be evaluated. Only eleven of these were not suitable for evaluation. In those cases where only one fragment could be identified the cultivar was considered homozygous for that loci. Because the null alleles cannot be excluded, heterozygous values may be underestimated. A total of 216 polymorphic fragments were amplified with the eight primer pairs. The average 
Table 1 Cultivars obtained from the pear gene bank in Keszthely at the University of Pannonia, Georgikon Faculty, Department of Horticulture in Hungary and the collection of BOKU at Jedlersdorf, Austria

\begin{tabular}{|c|c|}
\hline $\begin{array}{l}\text { Hungarian regional } \\
\text { cultivars }\end{array}$ & $\begin{array}{l}\text { Korai szagos, Kiss Margit, Fehérvári körte 1., Nyári körte Dunaföldvár, Piros nyári körte Bicske, Köcsög } \\
\text { körte VK 3, Szűcsi II., Csákvári nyári 010, Őszi körte Leányfalu, Mézes körte, Citrom körte, Köcsög } \\
\text { VK 2, Bikácsi nagy szegfü, Révész Bálint A, Köcsög körte, Nyári zöld kobak, Zsámbéki 214, Magyar } \\
\text { kobak, Selmeci körte II., Fehérvári körte, Szentendrei császár, Császár körte, Leányfalusi piros, } \\
\text { Macskafej, Szücsi IV., Szücsi szegfü típus, Szücsi körte Bore típus, Erdélyi II., 1/7 Ráckeve, Öszi } \\
\text { császár körte Törökbálint, Mandula vajkörte, Nagy szegfü körte, } 395 \text { Zöld Magdolna, Mezökövesdi 3, } \\
\text { Téli Kálmán, Nyári király körte, Móri császár, Erdélyi III., Fertődi rozsdás, Szűcsi III., Öszi pálinka, } \\
\text { Szobi legkorábbi, Solymári cukor, Mezőkövesdi 2, Mosolygó, Miklós, Fujtós körte, Mogyoródi óriás, } \\
\text { Piroska, }\end{array}$ \\
\hline $\begin{array}{l}\text { Cultivars of foreign } \\
\text { origin }\end{array}$ & $\begin{array}{l}\text { Hertich Bergamottja, Árpával érő, Nyári Kálmán, Bella di Giugno, Hóka, Nyári esperes, Tarjáni körte, } \\
\text { Mária Lujza,, Totyakos császár, Favrené, Aromata de Bistrica, Amanlis vaj Pákozd, Melló bárónő, } \\
\text { Pittmastoni hercegnő, Miniszter Lucius, Drouard elnök, Stössel Tábornok, Marianna hercegnő, Pap } \\
\text { körte igen bőtermő Sárospatak, Orient, Moon Geon, Izambert, Malinéri Jozefin }\end{array}$ \\
\hline $\begin{array}{l}\text { Standard cultivars at } \\
\text { Keszthely }\end{array}$ & Beurré Bosc (Bosc kobakja), Williams (Vilmos), Beurré d' Anjou, Hosui \\
\hline $\begin{array}{l}\text { Standard cultivars at } \\
\text { BOKU }\end{array}$ & $\begin{array}{l}\text { Abbé Fetel, Williams, Uta 12a, Packham's Triumph, Alexander Lucas, Beurré Bosc (Bosc } \\
\text { Flaschenbirne), Gute Louise }\end{array}$ \\
\hline
\end{tabular}

number of alleles were counted for $27 /$ loci. The fewest alleles (11) were obtained with the $\mathrm{CH} 04 \mathrm{e} 03$ primer pair, while the most (44) with $\mathrm{CH} 03 \mathrm{~g} 07$. Expected heterozygosity (He) was formed between 0.72 (CH04e03) and 0.95 (CH03g07), while the mean was 0.88 . Observed heterozygosity (Ho) was formed between 0.01 (CHO $4 \mathrm{e} 03$ ) and 1.00 (GD147), with an average of 0.80 (Table 2). The estimated frequency of null alleles gave positive results in three cases (CH04e03, CH03d12, CH3g07), but this only indicates the possibility of their presence.

Sehic et al. (2012), Gasi et al. (2013) and Queiroz et al. (2015), with similar markers, obtained a different result for the number of alleles. The number of found alleles was 104, 159, and 68, and the number of alleles per loci was 10.4, 14.5, and 11.3. The expected average heterozygosity was 0.78 and 0.806 (Gasi et al. 2013) and the observed heterozygosity was $0.74,0.81$ and 0.852 . The intervals of allele sizes were obtained by Puskás et al. (2015), we have seen similar values for four loci (EMPc11, EMPc117, CH05c06, CH01d09). The other four loci (CH03g07, CH03d12, GD147, $\mathrm{CH} 04 \mathrm{e} 03$ ) showed greater differences (Table 2).

The frequency of the measured fragment lengths per loci was also observed. The most frequent alleles are considered "wild type", and the other alleles could be formed by mutation. Big alleles with a frequency above 0.1 are highlighted.
The frequencies of alleles detected on the eight loci were divided into four categories. Only $6(2.8 \%)$ alleles belong to the very frequent category $(0.2$ and above). There were 40 alleles in the frequent category (18.5\%) which shows $0.05-0.2$ allele frequency. There were 109 alleles $(50.5 \%)$ in the rare category ranging from 0.01 to 0.05 . Besides the 261 polymorphisms, 68 alleles were unique; they occurred only once. There were also very rare alleles below the frequency of 0.01 , the number of these was $61(28.2 \%)$ and the seven pieces of rare alleles were put in this category in the case of the $\mathrm{CHO} 4 \mathrm{e} 03$ locus. The number of individual alleles per locus varied between three and 20. Sehic et al. (2012) found 20 unique alleles during their examinations of 86 samples with 10 markers. The large number of frequent and rare alleles and the wide range of varieties in dendrograms confirm that the varieties tested have great value in terms of genetic diversity.

Cultivars that amplify one or two fragments per locus are considered diploid. This condition, in all eight loci, was only satisfied by 29 cultivars. Based on allele composition, 59 species appeared to be triploid. Three different alleles were detected on these loci, number1-4. The presence of more than two alleles per locus does not necessarily mean that the cultivar is polyploid. This may be due to measurement error and chimeric presence. 
Table 2 Characterization of eight SSR loci based on 88 cultivars and the comparison of intervals

\begin{tabular}{|c|c|c|c|c|c|c|c|}
\hline \multirow[t]{2}{*}{ Loci } & \multirow[t]{2}{*}{ Loci reference } & \multirow[t]{2}{*}{ Number of allels } & \multicolumn{2}{|c|}{ Allel size intervals } & \multirow[t]{2}{*}{$\mathrm{He}$} & \multirow[t]{2}{*}{ Ho } & \multirow[t]{2}{*}{$\mathrm{n}$} \\
\hline & & & our data & Puskás et al. (2015) & & & \\
\hline $\mathrm{CH} 04 \mathrm{e} 03$ & Liebhard et al. (2002) & 11 & $114-205$ & $169-229$ & 0.7206 & 0.0114 & 0.4122 \\
\hline $\mathrm{CH} 03 \mathrm{~d} 12$ & Liebhard et al. (2002) & 17 & $94-125$ & $83-159$ & 0.8628 & 0.6023 & 0.1399 \\
\hline GD147 & Hokanson et al. (1998) & 17 & $114-131$ & $123-167$ & 0.8551 & 1.0000 & -0.0781 \\
\hline EMPc11 & Fernández-Fernández et al. (2006) & 26 & $133-159$ & $127-174$ & 0.9138 & 0.9773 & -0.0332 \\
\hline $\mathrm{CH} 05 \mathrm{c} 06$ & Liebhard et al. (2002) & 28 & $78-118$ & $76-128$ & 0.8827 & 0.9545 & -0.0381 \\
\hline EMPc117 & Fernández-Fernández et al. (2006) & 36 & $86-135$ & $85-140$ & 0.9296 & 0.9773 & -0.0247 \\
\hline CH01d09 & Liebhard et al. (2002) & 37 & $124-170$ & $120-179$ & 0.9418 & 0.9886 & -0.0241 \\
\hline $\mathrm{CH} 03 \mathrm{~g} 07$ & Liebhard et al. (2002) & 44 & $191-309$ & $119-284$ & 0.9458 & 0.9205 & 0.0130 \\
\hline
\end{tabular}

Genetic diversity among the pear cultivars

We found different compositions of alleles in all 88 genotypes in our study. Cultivars were compared in the following groups during the evaluation.

Comparison of „reference” cultivars with the data of other literature and comparison of same cultivars obtained from Hungary, from the University of Pannonia in Keszthely, and from Austria from the University of Natural Resources and Life Sciences in Vienna like: 'Williams' (hungarian name: 'Vilmos'), 'Beurré Bosc' (hungarian name: 'Bosc kobakja'german name: 'Bosc Flaschenbirne').

Comparison of cultivars with the same names from Hungary: 'Korai szagos' A and B, 'Melló bárónő' A and $\mathrm{B}$, 'Nyári esperes' $\mathrm{A}$ and $\mathrm{B}$, 'Fehérvár körte' $\mathrm{A}$ and B, 'Császár körte' A and B.

Comparison of cultivars within the same types (Clones?): 'Fehérvári körte', 'Köcsög körte' 'Császár körte' types.

Comparison of cultivars whose names refer to the same place of the origin: erdélyi, mezőkövesdi, szücsi or leányfalusi.

The cluster analysis did not show significant clusters among the samples studied, possibly due to the high genetic diversity found in the study. In combination with the PCA some trends may be discussed (Fig. 1).

For example, according to our measurements, 'Nyári körte Dunaföldvár', is the farthest away from the common point, only about $50 \%$ of the alleles correspond to common ancestral alleles. Similarly, the distances of other types can be read. Even if differences were found, the dendrograms did not show clear clustering (Fig. 2).

Allele lengths of „standard" cultivars 'Williams' and 'Beurré Bosc' derived from BOKU were compared to Puskás et al. (2015) and we found 1-9 bp difference. This may be due to the use of chemicals and uses of different instruments. Later on, we employed these references as an ,internal standard” to compare the allele lengths of our measurements with the already known data. We got the same results with a difference of 1-3 bp for some loci as compared to the internal standard. All further results were standardized.

The allelic compositions of 'Williams' (from BOKU Vienna and from Keszthely) were shown to be the same genotype with only 1 bp difference, as it can be seen in the dendrogram. The alleles of 'Beurré Bosc' (from Keszthely and from Vienna were also similar but one more allele was found at three loci. They are closely according to the dendrogram of course. The two variants (A and B) of the 'Korai szagos' cultivar can be closely according to the dendrogram; 1 bp difference was found between their alleles. Probably they are the same cultivar from different regions in Hungary. Similar results were found in the case of 'Nyári esperes', 'Melló bárónő' and 'Császár körte' A and B variants. Only 1 and 2 bp differences were found too, which can also be due to an error in measurement. These differences are not significant, so these cultivars can be considered the same. Variants A and B of the 'Fehérvári körte', however, belong to the two main groups of the dendrogram, variant $\mathrm{B}$ shows three different loci 
Factorial analysis: (Axes 1/2)

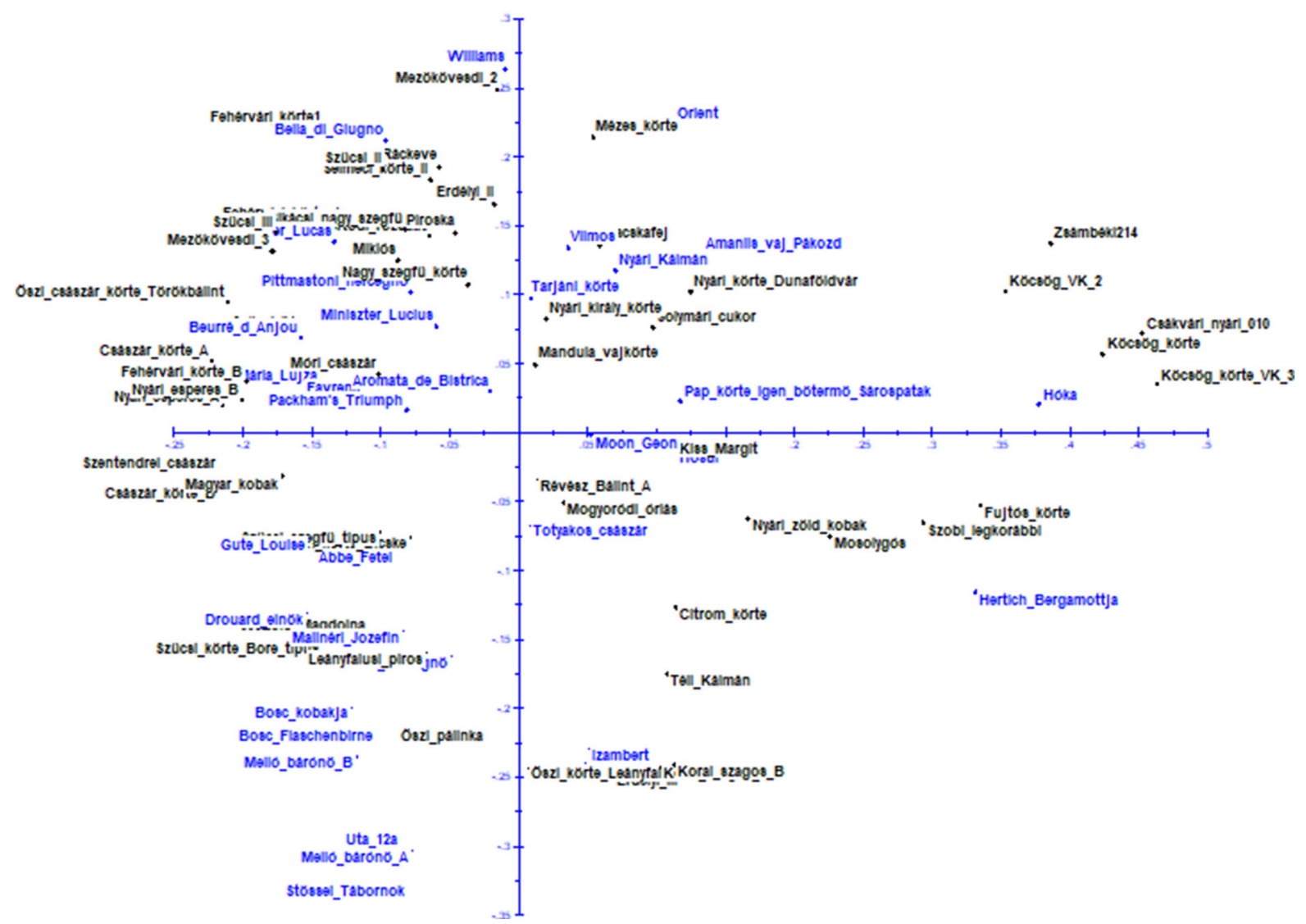

Fig. 1 Principal coordinates analysis with 88 pear samples analysed with 10 SSR loci plotted on the first two coordinates. Hungarian regional cultivars (black), Cultivars of foreign origin, Standard cultivars in Hungary and in Austria (blue). (Color figure online)

divergences of $1 \mathrm{bp}$ and has two loci with three alleles. Therefore, these variants are considered to be separate cultivars.

All six cultivars of 'Császár körte' belong to the same main branch of the dendrogram. A close relationship can be found between 'Császár körte', 'Móri császár' and 'Szentendrei császár'. The other two closely related cultivars, the 'Totyakos császár' and 'Öszi császár körte Törökbálint', are on the other branch. According to Szani (2012), the name of 'Császár körte' is an old-fashioned name, a kind of 'brand' of high quality pears. 'Császár körte' has several types with similar names. The three types of 'Köcsög körte' are closely related, with only two different loci in the number of alleles.

'Erdélyi körte II' and 'Erdélyi körte III' were on different main branches of the dendrogram, so there is no close relationship between them.
The 'Mezőkövesdi 2' and 'Mezőkövesdi 3 ' are on the same main branch, however their distance is larger, the number of common alleles is less than those of the two 'Erdélyi körte', so their relationship connection is very loose. Among the cultivars with Szücsi names, like 'Szücsi II.', 'Szücsi III.' and ' Szücsi szegfü' the relationship is very close. 'Szücsi IV.' and the 'Szücsi körte Bore típus' were found on separate main branches, so they do not have a close relationship with each other, neither with the other Szücsi type. The two 'Leányfalusi' types are not closely related, because they are located in two separate main branches. Among the Szegfü körte types, 'Bikácsi Nagy szegfü' and 'Nagy szegfü körte' were next to each other on the dendrogram, so their relationship is close. The 'Szücsi szegfü körte' is in another main branch. 
Fig. 2 Unweighted Neighbor-Joining tree of 88 pear cultivars. Hungarian regional cultivars (black), Cultivars of foreign origin, Standard cultivars in Hungary and in Austria (blue). (Color figure online)

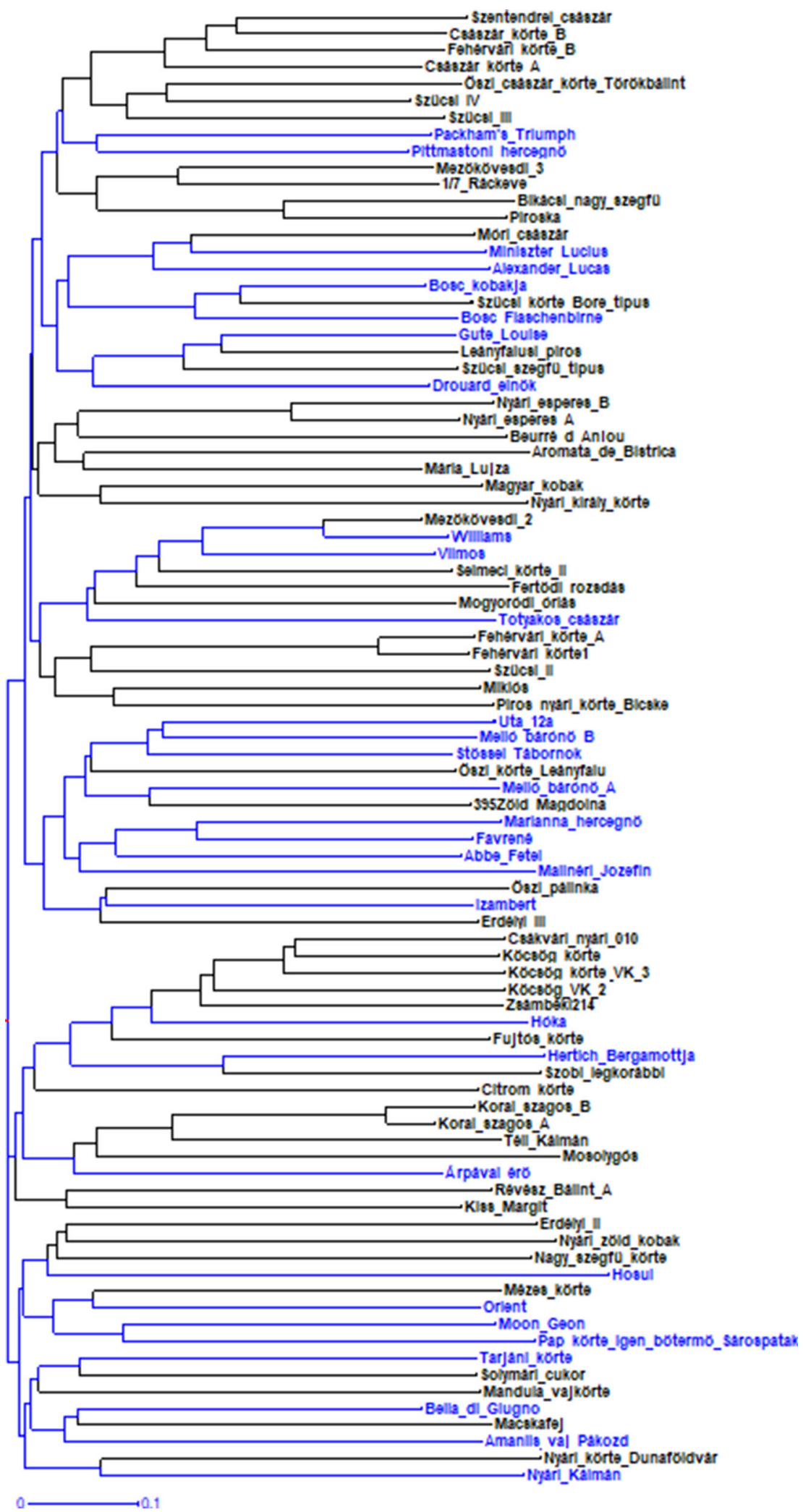


The 'Hosui' cultivar does not form a separate group in the dendrogram, although it is not the P. communis species but Pyrus pyrifolia. Postman et al. (2013) published a figure which shows the 'Hosui' cultivar is on another branch in the dendrogram, different from the Pyrus communis cultivars. There is a closer relationship between the 'Hosui' and some Hungarian cultivars, like 'Erdélyi II. ', 'Nyári zöld kobak' and 'Nagy szegfü körte' in our results.

The results clearly show the benefit and need of genetic identification of gene bank genotypes and cultivars. The developed protocol for molecular identification of pear cultivars stresses the need to implement reference samples that are firstly to define for each gene bank. In the case of the Hungarian Pear Gene Bank this is especially important (and laborious) since the genetic background exceeds the range of other gene banks due to historical reasons.

Acknowledgments Open access funding provided by University of Pannonia (PE). The publication is supported by the Hungarian Government and the European Union, with the co-funding of the European Regional Development Fund in the framework of the Széchenyi 2020 Programme GINOP-2.3.2-152016-00054 project.

Author contributions Gitta M. Kocsisné, Dávid Bolla and László Kocsis collected and prepared the samples, Dávid Bolla, Ulrike C.M. Anhalt-Brüderl analyzed the samples. Astrid Forneck, János Taller, Dávid Bolla, Ulrike C.M. AnhaltBrüderl statistically analyzed the data and prepared the figures, Dávid Bolla, Gitta M. Kocsisné and Ulrike C.M. Anhalt-Brüderl wrote the majority of the manuscript and László Kocsis, Astrid Forneck and János Taller revised it.

Funding This study was funded by the Hungarian Government and the European Union, with the co-funding of the European Regional Development Fund within the framework of the Széchenyi 2020 Programme, GINOP-2.3.215-2016-00054 project.

Data availability All data generated or analysed during this study are included in this published article (and its additional files).

\section{Compliance with ethical standards}

Conflict of interest The authors declare that they have no conflict of interest.

Open Access This article is licensed under a Creative Commons Attribution 4.0 International License, which permits use, sharing, adaptation, distribution and reproduction in any medium or format, as long as you give appropriate credit to the original author(s) and the source, provide a link to the Creative
Commons licence, and indicate if changes were made. The images or other third party material in this article are included in the article's Creative Commons licence, unless indicated otherwise in a credit line to the material. If material is not included in the article's Creative Commons licence and your intended use is not permitted by statutory regulation or exceeds the permitted use, you will need to obtain permission directly from the copyright holder. To view a copy of this licence, visit http://creativecommons.org/licenses/by/4.0/.

\section{References}

Barth S, Forneck A, Verzeletti F, Blaich R, Schumann F (2009) Genotypes and phenotypes of anex situ Vitis vinifera ssp. sylvestris (Gmel.) Beger germplasm collection from the Upper Rhine Valley. Genet Resour Crop Evol 56:1171-1181

Bellini E, Nin S, Natarelli L (2003) La conzervazione del germoplasma di pero in Ilalia. Frutticoltura, No, p 12

Brózik S, Nagy P, Szentiványi P (1976) Tervtanulmány a gyümölcstermő növények megőrzésére. GYDKFV Kiadvány, Budapest

Eccher T, Pontirolo R (2005) Old pear varieties in Northern Italy. Acta Hort 671:243-246

Evans KM, Fernández-Fernández F, Govan C (2009) Harmonising fingerprinting protocols to allow comparisons between germplasm collections-Pyrus. Acta Hort 814:103-106

Fernández-Fernández F, Harvey NG, James CM (2006) Isolation and characterization of polymorphic microsatellite markers from European pear (Pyrus communis L.). Mol Ecol Notes 6:1039-1041

Forneck A, Anhalt UCM, Mammerler R, Griesser M (2015) No evidence of superclones in leaf-feeding forms of austriangrape phylloxera (Daktulosphaira vitifoliae). Eur J Plant Pathol 142:441-448

Gascuel O (1997) Concerning the NJ algorithm and its unweighted version, UNJ. Mathematical hierarchies and biology DIMACS workshop, Discrete Mathematics and Theoretical Computer Science, vol 37. American Mathematical Society, Providence, pp 149-170

Gasi F, Kurtovic M, Kalamujic B, Pojskic N, Grahic J, Kaiser C, Meland M (2013) Assessment of European pear (Pyrus communis L.) genetic resources in Bosnia and Herzegovina using microsatellite markers. Sci Hortic 157:74-83

Göndörné (2000) Körte. Mezőgazda Kiadó, Budapest. pp. 17, 22, 37, 102-110

Hokanson SC, Szewc-McFadden AK, Lamboy WF, McFerson JK (1998) Microsatellite (SSR) markers reveal genetic identities, genetic diversity and relationships in a Malus $\times$ domestica Borkh. core subset collection. Theor Appl Genet 97:671-683

Hummer KE, Sugar D (1998) Pear genebank information on the worldwide web. Acta Hortucult 475:117-122

Iváncsics J (1994) Néhány magyar körte tájfajta virágzásának és termésének vizsgálata. Egyetemi doktori értekezés, Mosonmagyaróvár

Kim YK, Won KH, Lee UY, Yim SH, Shin IS, Kang SS, Han JD, Lee HC (2015) Genetic diversity of Asian and 
European pear using simple sequenced repeats markers analysis. Acta Hort 1094:67-73

Kocsisné M G (2006) Körtefajták értékelése a Georgikon Mezőgazdaságtudományi Kar génbankjában. $\mathrm{PhD}$ Thesis

Labuschagne I, Musacchi S, Nyéki J, Szabó Z (2011) The hungarian pear germplasm (Pyrus communis) as source of genetic variability for breeding programs. Acta Horticult 909:89-95

Ledó F (2016) Annual Report of hungarian fruit and vegetable sector. Fruit VeB Magyar Zöldség- Gyümölcs Szakmaközi Szervezet. p. 20.

Li L, Deng C, Knäbel M, Chagné D, Kumar S, Sun J, Zhang S, Wu J (2017) Integrated high-density consensus genetic map of Pyrus and anchoring of the 'Bartlett' v1.0 (Pyrus communis) genome. DNA Res 24(3):289-301

Liebhard R, Gianfranceschi L, Koller B, Ryder CD, Tarchini R, Van de Weg E, Gessler C (2002) Development and characterisation of 140 new microsatellites in apple (Malus $\times$ domestica Borkh). Mol Breed 10:217-241

Perrier X, Jacquemoud-Collet JP (2006) DARwin software. https://darwin.cirad.fr/. Accessed 1 June 2016

Postman J, Kim D, Bassil N (2013) OHxF paternity perplexes pear producers. J Am Pomol Soc 67(3):157-167

Postman J (2019) Pear germplasm needs and conservation. In: Korban SS (ed) The Pear Genom. Springer, Cham, p 315

Puskás M, Höfer M, Sestraş RE, Peil A, Sestraş AF, Hanke MV, Flachowsky H (2015) Molecular and flow cytometric evaluation of pear (Pyrus L.) genetic resources of the
German and Romanian national fruit collections. Genet Resour Crop Evolut 63:1023-1033

Queiroz A, Assuncao A, Ramadas I, Viegas W, Veloso MM (2015) Molecular characterization of Portuguese pear landraces (Pyrus communis L.) using SSR markers. Sci Hortic 183:72-76

Queiroz A, Guimaraes JB, Sanchez C, Simoes F, de Sousa RM, Viegas W, Veloso MM (2019) Genetic diversity and structure of the Portuguese pear (Pyrus communis L.) germplasm. Sustainability 11(19):5340

Saitou N, Nei M (1987) The neighbor-joining method: a new method for reconstructing phylogenetic trees. Mol Biol Evol 4(4):406-425

Sehic J, Garkava-Gustavsson L, Fernández-Fernández F, Nyboma H (2012) Genetic diversity in a collection of European pear (Pyrus communis) cultivars determined with SSR markers chosen by ECPGR. Sci Hortic 145:39-45

Szani Zs (2012) Főbb tájfajtáink. In: Nyéki J, Szabó T, Soltész M (eds) Körtefajták vizsgálata génbankokban. Debreceni Egyetem AGTC MÉK Kertészettudományi Intézet, Debrecen, p 58

Publisher's Note Springer Nature remains neutral with regard to jurisdictional claims in published maps and institutional affiliations. 